\title{
Journal of Global Catholicism
}

Volume 2

Issue 1 African Catholicism: Retrospect and Prospect

Article 2

December 2017

\section{The Ecclesiology of Pope Francis and the Future of the Church in Africa}

Bradford E. Hinze

Fordham University, bhinze@fordham.edu

Follow this and additional works at: https://crossworks.holycross.edu/jgc

Part of the African Studies Commons, Anthropology Commons, Catholic Studies Commons, Christian Denominations and Sects Commons, Christianity Commons, Comparative Methodologies and Theories Commons, Comparative Philosophy Commons, $\underline{\text { Cultural History }}$ Commons, Digital Humanities Commons, Hindu Studies Commons, History of Christianity Commons, History of Religion Commons, History of Religions of Western Origin Commons, $\underline{\text { Inequality and Stratification Commons, Intellectual History Commons, International Relations }}$ Commons, Missions and World Christianity Commons, Near and Middle Eastern Studies Commons, Other International and Area Studies Commons, Practical Theology Commons, Race and Ethnicity Commons, Race, Ethnicity and Post-Colonial Studies Commons, Regional Sociology Commons, and the Religious Thought, Theology and Philosophy of Religion Commons

\section{Recommended Citation}

Hinze, Bradford E. (2017) "The Ecclesiology of Pope Francis and the Future of the Church in Africa," Journal of Global Catholicism: Vol. 2: Iss. 1, Article 2. p.6-33.

DOI: $10.32436 / 2475-6423.1019$

Available at: https://crossworks.holycross.edu/jgc/vol2/iss1/2

This Article is brought to you for free and open access by CrossWorks. It has been accepted for inclusion in Journal of Global Catholicism by an authorized editor of CrossWorks. 


\section{BRADFORD E. HINZE}

\section{The Ecclesiology of Pope Francis and the Future of the Church in Africa}
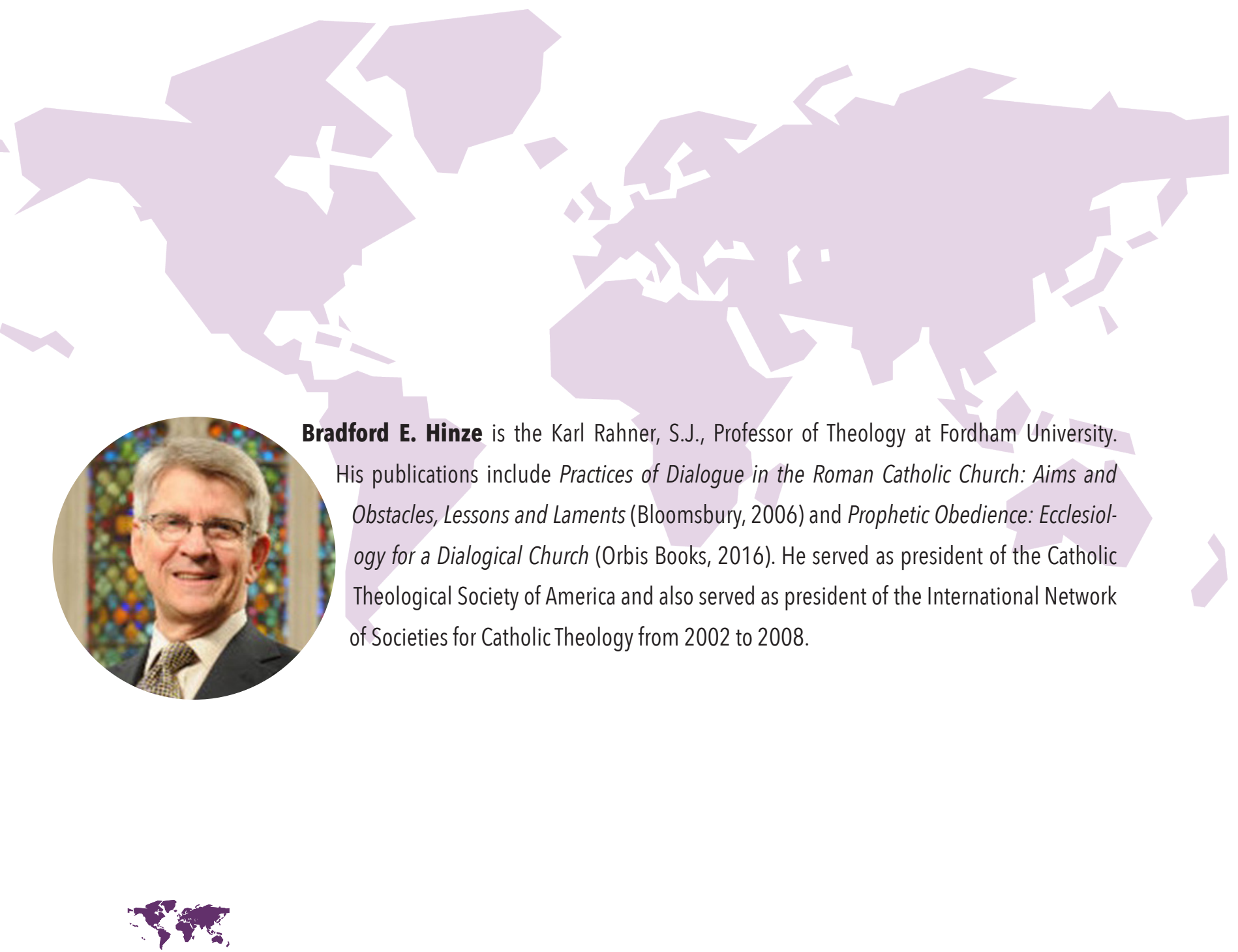
$\mathrm{T}$ his essay will explore the ecclesiology of Pope Francis and consider its significance for the future of the Church in Africa. I will do so by describing four basic ingredients in the pope's ecclesiology. I will then explore how these elements work together to challenge centralization, clericalism, and triumphalism in the Church by promoting practices of synodality and how these elements support the Church's mission to work against forms of colonialism, neo-colonialism, and the most fundamental matrix of colonial power by advancing radical democracy in society. This is Pope Francis's agenda for global Catholicism - synodality and democracy - but it must take shape and be actualized in distinctive ways based on the geographical, social, cultural, and economic realities faced by distinctive continents, nations, and civic areas, including across the great continent of Africa.

It is widely recognized that Pope Francis has initiated a new phase in the reception of Vatican II's vision of the Church. By so doing, he has advanced in fresh ways the Church's mission of mercy and work for justice in response to the cry of the poor and the cry of the earth.

I write as an ecclesiologist who has, for over twenty-five years, studied the reception and implementation of the Second Vatican Council in the Church across the spectrum of institutional levels of the global Church, but especially in national, diocesan, and parish contexts in the United States. ${ }^{1}$ More recently, my research and writing have focused on the use of dialogical processes for group discernment and decision making in the local church in parishes and in community organizing in civil society. Thus, I have concentrated on the use of group dialogue processes in local expressions of synodality in parishes and, at the diocesan level, in the collective discernment of the Church's mission and pastoral priorities. I have also devoted considerable attention to how analogous forms of group dialogue have been used in the promotion of grassroots democracy in civic society, and in particular how Catholic parishes have participated in broad-based community organizing with people of other Christian churches, other faiths, and other worldviews to promote par-

1 Bradford E. Hinze, Prophetic Obedience: Ecclesiology for a Dialogical Church (Maryknoll, NY: Orbis Books, 2016); Hinze, Practices of Dialogue in the Roman Catholic Church (New York: Continuum, 2006). 
ticipatory governance and economic democracy. These are distinctive priorities in the documents of Vatican II, and Pope Francis has given special attention to them. In this essay, I will briefly recall main themes from Pope Francis's ecclesiology that have become widely recognized. I will give hefty quotations from the pope's writings and speeches, because he is such an effective communicator. Then, as someone who has followed the work of theologians and the Catholic Church in various centers in sub-Saharan Africa for a couple of decades, I will consider the significance of Pope Francis's ecclesiology for the future of the Church in Africa.

Let me begin by identifying four ecclesiological themes accentuated by Pope Francis and which are also important as we think about the future of the Church in Africa: the people of God, the sense of the faithful, reality and the signs of the times, and the call to a synodal Church. I will discuss each of these themes in more details in the following pages. When we think about what is distinctive about Pope Francis's vision of the Church, many themes come to mind. Shortly after being elected, he put it this way: "How I would like a church that is poor and for the poor." ${ }^{2}$ This was the great desire of Pope John XXIII on the eve of the Second Vatican Council, and it marked a defining agenda among a group of bishops participating in the council. ${ }^{3}$ It cannot be denied that, from the first day of his pontificate, Pope Francis has devoted himself to local churches that are poor and to poor people around the world. This is one main reason why he chose Francis for his name after Francis of Assisi, the friend of the poor; it captures the preferential option for the poor especially associated with the Church in Latin America. As I will argue at the end of this essay, while it is true that Francis has given special emphasis to the poor, he has done so to draw widespread attention to the Church's mission to alleviate the effects of poverty that affect daily life and living conditions as well as to struggle

2 Joshua J. McElwee, "Pope Francis: 'I would love a church that is poor,"' National Catholic Reporter, March 16, 2013, https://www.ncronline.org/blogs/francis-chronicles/pope-francis-i-would-lovechurch-poor.

3 Hinze, "Vatican II and U.S. Catholic Communities Promoting Grassroots Democracy," in The Legacy of Vatican II, eds. Massimo Faggioli and Andrea Vicini (New York: Paulist Press, 2015), 156-57; Alberto Melloni, "Poverty of the Church-Poverty of Culture: A Contribution of Giuseppi Dossetti to Vatican II," Theological Studies 75 (2014): 485-501. 
against the causes of poverty - the social, cultural, and institutional patterns of exclusion - that deleteriously affect people.

Another defining feature of the pope's ecclesiology is his summons for all the members of the Church to embrace a missionary option - a mission of mercy and justice - a missionary option as a field hospital in a wounded world. Mindful of these defining characteristics of Pope Francis's teachings, I wish to concentrate on four themes that demonstrate that Pope Francis has initiated a new phase in the reception of Vatican II. These themes will provide a framework for considering two special topics that are particularly important for the pope and for the Church in Africa.

\section{THE PEOPLE OF GOD}

It is beyond dispute that Pope Francis has initiated a new phase in the reception of Vatican II by returning the Church's attention to a cluster of theological ideas around the teaching of the council associated with the vision of the Church as the people of God. This motif captivated many members of the Church around the world after the Dogmatic Constitution of the Church (Lumen Gentium) ${ }^{4}$ was issued, which gave special attention to the Church as people of God in chapter two and in various other documents. Yet this motif has been overshadowed - virtually eclipsed - since 1985 when the Extraordinary Synod of Bishops, in reviewing the aftermath of Vatican II, maintained that communion ecclesiology was central to the documents. This orientation came to define the papacies of John Paul II and Benedict XVI. Francis changed this in his first major interview after becoming pope in 2013 when he said, "the image of the Church I like is that of the holy, faithful people of God." 5 During this interview, he sounded key themes closely associated with the motif in Vatican II documents of the Church as a people of God: the sense of the faithful; the historical and eschatological character of the people of God journeying together; and heeding the signs of the times in reality.

4 Paul VI, Lumen Gentium [Dogmatic Constitution on the Church] (herafter, LG), Vatican website, November 21, 1964, last accessed December 18, 2017, http://www.vatican.va/archive/hist_councils/ii_vatican_council/documents/vat-ii_const_19641121_lumen-gentium_en.html.

5 Antonio Spadaro, "A Big Heart Open to God," America, September 30, 2013, https://www.americamagazine.org/faith/2013/09/30/big-heart-open-god-interview-pope-francis. 
For Francis, the image of the people of God is not just a central idea; rather, it reflects a style of spirituality, a practical way of life, and a pastoral style of ministry. ${ }^{6}$ People outside of Latin America are now gaining a better understanding of the historical reality that there were influential theologians - not all liberation theologians - who devoted special attention to the "people of God" vision of the Church and, with it, attention to the daily life and cultures of local peoples.

It is this attention to the diverse daily lives of people, their diverse local cultures, and popular forms of piety that is so central for Pope Francis. We clearly hear this in a statement in Evangelii Gaudium where he speaks about "a people of many faces": ${ }^{7}$

The people of God is incarnate in the peoples of the earth, each of which has its own culture. The concept of culture is valuable for grasping the various expressions of the Christian life present in God's people. It has to do with the lifestyle of a given society, the specific way in which its members relate to one another, to other creatures, and to God. Understood in this way, culture embraces the totality of a people's life. Each people, in the course of its history, develops its culture with legitimate autonomy. This is due to the fact that the human person, "by nature stands completely in need of life in society" and always exists in reference to society, finding there a concrete way of relating to reality. The human person is always situated in a culture: "nature and culture are intimately linked." Grace supposes culture, and God's gift becomes flesh in the culture of those who receive it.

This focus on the everyday culture of the people of God is also found in Pope Francis's encyclical, Laudato Si', when he writes about the importance of appreciating

6 See the analysis of the theology of the people of God by Lucchetti Bingemer, "The Sensus Fidei in the Recent History of the Latin American Church," CTSA Proceedings 70 (2015): 48-59; and by Austin Ivereigh, The Great Reformer: Francis and the Making of a Radical Pope (New York: Picador, 2015), 110-117.

7 Francis, Evangelii Gaudium [Apostolic Exhortation on the Proclamation of the Gospel in Today's World] (hereafter, EG), Vatican website, November 24, 2013, 115-118, last accessed December 18, 2017, http://w2.vatican.va/content/francesco/en/apost_exhortations/documents/papa-francesco_esortazione-ap_20131124_evangelii-gaudium.html. 
local cultural ecologies ${ }^{8}$ and especially the ecology of everyday life.

\section{THE SENSE OF THE FAITHFUL}

For Pope Francis, the vision of the Church as the people of God is closely related with the ideas in Lumen Gentium of the sense of the faith of all the people of God. ${ }^{9}$ This chapter developed the theme that, through baptism, all the faithful are anointed with the Spirit of God and are gifted and called to participate actively in the priestly, prophetic, and kingly messianic offices of Christ in the life and mission of the Church. In particular, the teaching about the individual person's instinct of faith or sense of the faith - and derivatively, the community's sense of the faithful — is based on this passage. Through the baptismal anointing of the Spirit, the people of God - individually and collectively - come to participate in the prophetic office of Jesus Christ in truthful witness and missionary outreach.

To say that, through baptism, Christians participate in the prophetic office of Christ means that they have come to recognize and receive the truth of the gospel in their lives. And thus, they are called to be truthful witnesses of the faith, to live out and apply the gospel faithfully and creatively in their daily lives. As such, the prophetic people of God are not only, in their own way, guardians of the apostolic faith of the Church with the teaching authority of the bishops, but also, by applying the faith in their everyday lives, they are also the source of doctrinal development and, thus, should be continually consulted and collaborated with in the discernment of the faith. ${ }^{10}$

Based on this teaching, Pope Francis has challenged bishops, priests, and theologians to be in close contact with the sense of the faithful - to pray and worship

8 Francis, Laudato Si' [Encyclical Letter on Care for Our Common Home] (hereafter, LS), Vatican website, May 24, 2015, 143-146, last accessed December 18, 2017, http://w2.vatican.va/content/ francesco/en/encyclicals/documents/papa-francesco_20150524_enciclica-laudato-si.html.

9 Paul VI, $L G, 12$.

10 Francis, "Address at the Ceremony Commemorating the 50th Anniversary of the Institution of the Synod of Bishops," Vatican website, October 17, 2015, last accessed December 18, 2017, http://w2.vatican.va/content/francesco/en/speeches/2015/october/documents/papa-francesco_20151017_50-anniversario-sinodo.html: "The sensus fidei prevents a rigid separation between an Ecclesia docens and an Ecclesia discerns, since the flock likewise has an instinctive ability to discern the new ways that the Lord is revealing to the Church." 
with the faithful, to eat and drink with them, to collaborate with them in religious education and in works of mercy and to work for justice - to be totally immersed with the sense of the faithful people of God in local churches and communities and among populations that have been excluded and on the periphery of the Church around the world. These people of God provide a reliable and challenging source and norm for the confession of faith.

As we read in Evangelii Gaudium:

In all the baptized, from first to last, the sanctifying power of the Spirit is at work, impelling us to evangelization. The people of God is holy thanks to this anointing, which makes it infallible in credendo. This means that it does not err in faith, even though it may not find words to explain that faith. The Spirit guides it in truth and leads it to salvation (96). As part of his mysterious love for humanity, God furnishes the totality of the faithful with an instinct of faith - sensus fidei - which helps them to discern what is truly of God. The presence of the Spirit gives Christians a certain connaturality with divine realities and a wisdom which enables them to grasp those realities intuitively, even when they lack the wherewithal to give them precise expression. ${ }^{11}$

\section{HEEDING REALITY AND THE SIGNS OF THE TIMES}

Building on what he has said about the people of God and the sense of the faithful, the pope has given new attention to Vatican II's theme of heeding "the signs of the times." This is a particular mark of the prophetic pilgrim people of God and reflects the inductive "See, Judge, Act" methodology of Catholic action associated with Joseph Cardign's Catholic Worker Youth Movement which informed the methodology employed by the Latin American Bishops Conferences (Consejo Episcopal Latinoamericano, CELAM) in Medellín, Puebla, and Aparecida. ${ }^{12}$ Through CELAM, Pope Francis has been deeply formed by this methodology, which is in keeping with his Ignatian approach to discernment.

11 Francis, EG, 119.

12 This connection is developed by Juan Carlos Scannone, "Gaudium et Spes and the Unfinished Agenda of Vatican II," filmed November 12, 2015 at Georgetown University, Washington, D.C., video, 1:46:17, https://youtu.be/94fs48fzsPg; and by Hinze, Prophetic Obedience, 7-9. 
I also believe that an important connection can be made between his promotion of heeding the signs of the times and his axiom that "realities are greater than ideas."13 During his years in the seminary, Jorge Mario Bergoglio encountered the deductive methodology of manualist theology which was rejected at Vatican II, but it is also the case, we are told by one of his biographers, that Bergoglio resisted a deductive approach to sociology and Marxism, particularly during his years at the Colegio Máximo de San José. ${ }^{14}$ This emphasis on the signs of the times and the reality principle helps us to appreciate the pope's regular critique of ideologies that fail to grasp reality and, in fact, distort it.

If we were going to identify the realities to which Pope Francis has given special attention, we would certainly include the reality of the poor, the increasing problems associated with global poverty, and neoliberal economic patterns of exclusion that contribute to increasing economic injustice and disparity.

The second area of reality that has received the pope's attention has been the problem of the environmental crisis. This reality has certainly been a concern for John Paul II and Benedict XVI, but what is truly remarkable is Pope Francis's effort to call attention to this multifaceted reality - to develop an integral ecological approach, not only in terms of experience (environment, biodiversity, water) but also in terms of science, culture, and economics.

\section{FINDING OUR WAY TOGETHER: THE CALL TO BE A SYNODAL CHURCH}

Synod is a word that comes from the Greek word synódos; the prefix syn means "with" or "together," and ódos means "way" or "journey." Thus, synódos can be translated as "the way together." The Acts of the Apostles refers six times to Christianity as "the Way" (ódos), as in "the way of the Lord." 15 In the second and third centuries, Christians started using the word synod to describe "a gathering" of leaders and disciples and "a communal practice and institution" dedicated to "finding our way together" through group dialogue — honest conversation and attentive listening -

13 Francis, $E G, 231$.

14 Ivereigh, The Great Reformer.

15 Acts $18: 25 ; 19: 9,23 ; 22: 4 ; 24: 14,22)$; cf. "prepare the way of the Lord" in Isaiah 40:3. 
14 The Ecclesiology of Pope Francis and the Future of the Church in Africa

aimed at group discernment and decision making. Synodality means finding our way together through group dialogue and discernment.

Francis's commitment to this vision of synodality reflects his Jesuit training in the spirituality and "way of proceeding" of Ignatius of Loyola and his long-time experience of collaborating with the Latin American Bishops' Conference. When he commemorated the 50th anniversary of the institution of the Synod of Bishops on October 17, 2015, he chose to speak of synods in terms of "journeying together": "It is precisely this path of synodality which God expects of the Church of the third millennium.... Journeying together — laity, pastors, the Bishop of Rome - is an easy concept to put into words, but not so easy to put into practice." ${ }^{16}$ All of the people of God should participate in evangelization and should not be viewed as passive recipients. Everyone participates in the listening and the teaching church, and "the flock ... has an instinctive ability to discern news ways that the Lord is revealing to the Church." ${ }^{17}$

When Pope Francis speaks about synodality, he is not only speaking about official Ecumenical Synods (often referred to as Ecumenical Councils-from the Council of Nicaea in 325 to Vatican II ending in 1965) or the Synods of Bishops promoted since Vatican II, but by extension, he is also speaking about episcopal conferences, as well as diocesan pastoral synods and councils and parish pastoral councils.

Pope Francis gives special attention to the role of listening and honest speaking in synods. On listening, he writes: "A synodal Church is a Church which listens, which realizes that listening 'is more than simply hearing.' It is a mutual listening in which everyone has something to learn. The faithful people, the college of bishops, the Bishop of Rome: all listening to each other, and all listening to the

16 Francis, "Address at the Ceremony."

17 Ibid. See Francis, "Address to the Leadership of the Episcopal Conferences of Latin America During the General Coordination Meeting," Vatican website, July 28, 2013, sec. 5.4, last accessed December 18, 2017, https://w2.vatican.va/content/francesco/en/speeches/2013/july/documents/ papa-francesco_20130728_gmg-celam-rio.html; and Francis, "Meeting with the Clergy, Consecrated People, and Members of Diocesan Pastoral Councils," Vatican website, October 24, 2013, last accessed December 18, 2017, https://w2.vatican.va/content/francesco/en/speeches/2013/ october/documents/papa-francesco_20131004_clero-assisi.html. 
Holy Spirit, the 'Spirit of truth' (John 14:17), in order to know what he 'says to the Churches' (Rev 2:7).” ${ }^{18}$

Francis also passionately denounces efforts to control honest speaking in synods and has counseled no self-censuring, and there is a backstory here that will explain his rationale. It is a well-known fact that, at synods and in other places of public speech in the Church, certain topics were considered taboo and certain church officials policed discussion, guarding against these issues being raised. At the synod of bishops held in 2014, Pope Francis addressed a complaint of many bishops attending synods since the mid-1980s: that there were cardinals in the Roman curia who restricted discussion of certain topics in small language groups. Some issues could be debated at synods, but not others. When priesthood was discussed, for instance, participants were scolded for bringing up the topic of married priests, and since 1994, the ordination of women has been, of course, a taboo subject. ${ }^{19}$ During the synod on the family in the 1980s, bishops were told they could not discuss artificial birth control. ${ }^{20}$ Pope Francis related a story of his own: at the 2001 synod he attended, "there was a cardinal who told us what should be discussed and what should not. This will not happen now." ${ }^{21}$ Why did he raise this issue before these synods on the family? He certainly wanted to encourage bishops to speak out honestly on possibly controversial topics such as communion for the divorced and remarried, cohabitation, and gay and lesbian Catholics who were in active, and frequently committed, relationships. I can't help but think that Francis promotes open speech on controversial subjects in the Church, because this is what participants at CELAM do during their General Conferences of the Episcopal Conference.

18 Francis, EG, 171.

19 John Paul II, Ordinatio Sacerdotalis [Apostolic Letter on Reserving Priestly Ordination to Men Alone], Vatican website, May 5, 1994, last accessed December 18, 2017, https://w2.vatican.val content/john-paul-ii/en/apost_letters/1994/documents/hf_jp-ii_apl_19940522_ordinatio-sacerdotalis.html.

20 And during one synod, certain bishops wanted to talk about the need for decentralization in the Church by using the category "subsidiarity" introduced by Pope Leo XIII in Rerum Novarum in 1891, but this topic and word were excised from the final documents.

21 Thomas Reese, S.J., "How the Synod Process is Different under Pope Francis," National Catholic Reporter, October 17, 2014, https://www.ncronline.org/blogs/faith-and-justice/how-synod-process-different-under-pope-francis. 
As a result, Pope Francis challenged the policy and practice of restricting dialogue in October 2014 before that synod began:

You [bishops gathered here from around the world] bring the voice of the Particular Churches, assembled at the level of local Churches through the Bishops' Conferences. The Universal Church and the Particular Churches are divine institutions; the local Churches are thus understood as human institutions. You will give voice in synodality. It is a great responsibility: to bring the realities and problems of the Churches, in order to help them to walk on that path that is the Gospel of the family.

One general and basic condition is this: speaking honestly. Let no one say: "I cannot say this, they will think this or [that] of me ...." It is necessary to say with parrhesia [with honesty] all that one feels. ${ }^{22}$ After the last [meeting of the Cardinals], in which the family was discussed, a Cardinal wrote to me, saying: what a shame that several Cardinals did not have the courage to say certain things out of respect for the Pope, perhaps believing that the Pope might think something else. This is not good, this is not synodality, because it is necessary to say all that, in the Lord, one feels the need to say: without polite deference, without hesitation. And, at the same time, one must listen with humility and welcome, with an open heart, what your brothers say. Synodality is exercised with these two approaches.

For this reason I ask of you, please, to employ these approaches as brothers in the Lord: speaking with parrhesia and listening with humility. ... Dear brothers, let us all collaborate so that the dynamic of synodality shines forth. ${ }^{23}$

22 This term parrhesia means to speak honestly, candidly, or freely. Sometimes, it means to speak boldly before political or religious leaders. The topic of parrhesia, or "fearless speech" as it has sometimes been translated, became important in the later writings of Michel Foucault. See the exploration of these materials by Torben B. Dyrberg, Foucault on the Politics of Parrhesia (New York: Palgrave Macmillan, 2014).

23 "And do so with great tranquility and peace, so that the Synod may always unfold cum Petro et sub Petro, and the presence of the pope is a guarantee for all and a safeguard of the faith": Francis, "Greeting to the Synod Fathers during the First General Congregation of the Third Extraordinary General Assembly of the Synod of Bishops," Vatican website, October 6, 2014, last accessed December 18, 2017, https://w2.vatican.va/content/francesco/en/speeches/2014/october/docu- 
As Pope Francis is well aware, when we speak honestly with one another and perhaps more so in groups, there can arise conflicts and debates. He addresses this issue in Evangelii Gaudium:

$[\mathrm{C}]$ onflict cannot be ignored or concealed. It has to be faced ... [T]o build communion amid disagreement ... can only be achieved by those great persons who are willing to go beyond the surface of the conflict and to see others in their deepest dignity. This requires acknowledging a principle indispensable to the building of friendship in society: namely, that unity is greater than conflict. Solidarity, in its deepest and most challenging sense, thus becomes a way of making history in a life setting where conflicts, tensions and opposition can achieve a diversified and life-giving unity. ${ }^{24}$

In the words of Pope Francis: "In a synodal Church, the Synod of Bishops is only the most evident manifestation of a dynamism of communion which inspires all ecclesial decisions. ${ }^{25}$ He differentiates three levels of synodality in the Church. At the first level, he identifies synodal structures in particular or local churches - diocesan synods, presbyteral councils, college of consultors, chapters of canons, and pastoral councils. Through these structures, leaders stay connected to the base, the people, and their daily problems, "even when they [these processes] prove wearisome. The second level is that of Ecclesiastical Provinces and Ecclesiastical Regions, Particular Councils and, in a special way, Conferences of Bishops ... [which can foster] a sound 'decentralization."'26 And the third level is that of the universal church and the practice of the Synod of Bishops. Thus, at this level, "episcopal collegiality" and an "entirely synodal Church" manifest "the collegialitas affectiva, which can also become in certain circumstances 'effective,' joining the Bishops among themselves and with the Pope in solicitude for the People of God."27

ments/papa-francesco_20141006_padri-sinodali.html. The consistory he mentions took place in February 2014.

24 Francis, $E G, 226,228$.

25 Francis, "Address at the Ceremony."

26 Ibid.

27 Ibid. This last mention of affective and effective collegiality, which implies a further clarification of the pope's position, references Pope John Paul II in Pastores Gregis [Post-Synod Apostolic Exhortation for the Hope of the World], Vatican website, October 16, 2003, 8, last accessed December 
It is thus a wonderful development - and not surprising - that the pope has given new attention to what episcopal conferences around the world are teaching the universal Church. In his apostolic exhortation, Evangelii Gaudium, and in his encyclical, Laudato $S i$, he has quoted the works of numerous episcopal conferences around the world, bringing them into his papal teaching. This practice is entirely consistent with what he says in Evangelii Gaudium about the relation of globalization and localization in terms of the polyhedron, which conveys his polycentric vision of the Church:

We need to sink our roots deeper into the fertile soil and history of our native place, which is a gift of God. We can work on a small scale, in our own neighborhood, but with a larger perspective. Nor do people who wholeheartedly enter into the life of a community need to lose their individualism or hide their identity; instead, they receive new impulses to personal growth. The global need not stifle, nor the particular prove barren.

Here our model is not the sphere, which is no greater than its parts, where every point is equidistant from the center, and there are no differences between them. Instead, it is the polyhedron, which reflects the convergence of all its parts, each of which preserves its distinctiveness. Pastoral and political activity alike seek to gather in this polyhedron the best of each. There is a place for the poor and their culture, their aspirations and their potential. Even people who can be considered dubious on account of their errors have something to offer which must not be overlooked. It is the convergence of peoples who, within the universal order, maintain their own individuality; it is the sum total of persons within a society which pursues the common good, which truly has a place for everyone. ${ }^{28}$

What Pope Francis has said about the people of God, the sense of the faith of God's people, the signs of the times, and synodality, provide the framework for his

18, 2017, http://w2.vatican.va/content/john-paul-ii/en/apost_exhortations/documents/hf_jpii_exh_20031016_pastores-gregis.html.

28 Francis, EG, 235-236. 
understanding of the missionary character of the Church, its mission of mercy and inclusion, and performing this mission as a field hospital for people wounded in and by the world.

\section{THE FUTURE OF THE CHURCH IN AFRICA: DECENTRALIZATION AND SYNODALITY}

I have introduced four main themes in Pope Francis's ecclesiology that provide a framework for his vision of the Church's mission of mercy, which he has described as serving the role of a field hospital, something that has captured the imaginations and hearts of many Catholics and non-Catholics alike. Another way of approaching the heart of his agenda is to consider two of his critical agendas: decentralization and decolonization. His remedy for the problems associated with centralization in the Church - triumphalism, clericalism, and infantilizing the laity - requires advancing a synodal approach to dialogue and discernment at the Church's various levels. His remedy for the problems associated with colonialism and neo-colonialism requires the promotion of grassroots democracy.

The future of the Church in Africa, according to Pope Francis's teaching, must be based on advancing synodality and democracy. I have already outlined what is required in promoting the synodality of the Church. What I have yet to include in this outline is the role of certain metaphors the pope is fond of using in this regard. He often speaks about bishops, theologians, clergy, and lay pastoral workers having the smell of the sheep and dirty soles on their shoes. This is his colloquial way of saying that all pastoral figures must be close to their people and their concerns. $\mathrm{He}$ also says that pastoral ministers should be in close contact with local communities, specifically with their particular cultures and their indigenous forms of piety. This provides the cultural vernacular, dialect, and idiom that are necessary for communicating with the faithful so as to find out about their aspirations, their concerns, their dreams, and the reasons for their grief and frustration.

When Francis meets with bishops, clergy, and lay pastoral leaders to discuss the problems associated with their ministry, he does not explicitly speak about social sin in the Church or institutional sin. It is interesting to note that, in significant 
ways, Francis continues the legacy of John Paul II by denouncing social sin and the social structures of sin in society and the Church, but unlike John Paul II, Francis rarely — if ever — uses these terms.

But what exactly is Francis's approach to social sin or structural sin in the Church? This pope is a champion of personal conversion and structural reform. And while he acknowledges the personal intentional sources of sin in the Church (as was prominent in John Paul II's writings, reflecting his training in philosophical phenomenology) and affirms the importance of intentionality, Francis also makes room for unconscious and unintentional dimensions that are operative in the Church's social practices and structures, and this reveals the impact of the Latin American Bishops Conference (CELAM) going back to the General Conference of Medellín.

On no less than three occasions during his first two years as pope, Francis called for an examination of conscience - among bishops, priests, and pastoral workers, but also among a narrower audience comprised of curial officials - to draw attention to what can be characterized as social sin or structures of sin in the Church. In these contexts, Francis focuses on three particular sources of structural sin. First, he gives special attention to pathologies of power associated with corporate corruption as well as with clericalism and the pathos of curial centralization. Second, he frequently returns to the role of ideologies and ideological elites with their distinctive approach to knowledge and power. And third, he occasionally mentions the influence of demonic powers on individuals and groups. These three factors contribute to the subjugation of members and groups within the Church. They are not traceable or reducible to individual intentional acts and personal responsibilities but may be a part of an historical order of things that has been handed on through canon law, ritual rubrics, bureaucratic policies and practices, and spiritual disciplines. These modes of discourse, discipline, and identity patterns can come to the surface in an examination of conscience that serves as an examination of consciousness, the half-conscious, and the unconscious in a purifying labor required for a change of heart and a change of structures.

Francis identifies two related kinds of pathology of power in the Church. The first kind is clericalism. He describes this in terms of the failure of pastors, bishops, and 
priests to foster the mission of the lay faithful and their freedom: by manipulating them or infantilizing them; by not encouraging them to develop their skills of personal discernment in the interests of mature decision-making; and by discouraging their participation in the collective discernment of the Church beginning at the parish level, but also at higher organizational levels in the Church. ${ }^{29}$

Francis identifies a second kind of pathology of power when he spoke of "more common "curial diseases" before Christmas in 2014 when he led the curia in an examination of conscience. He considered whether certain members of the curia have "the sickness of feeling oneself 'immortal,' 'immune' or in fact 'indispensible' [which] often stems from the pathology of power ... a superiority complex, [which arises] from a narcissism [that] passionately gazes at its own image and does not see the image of God imprinted on the face of others, especially the weakest and those most in need." ${ }^{30}$ This disease of indispensability and superiority is often linked to a "disease of worldly profit, of forms of self-exhibition, [which] turns [the curial official's] service into power, and his power into a commodity in order to gain worldly profit or even greater power." 31

A second source of structural sin is associated with the temptation among ordained and lay leaders to embrace and act out of an ideology, that is, a particular theory, idea, or program championed by an elitist group and confused with the saving Gospel message. This ideological use of elitist power operates as an "antiseptic" hermeneutic developed for the poor and marginalized, but without sufficiently engaging the sense of the faith of the people of God in discernment and attentively gazing upon reality with the eyes of discipleship.

29 "Do we make the lay faithful sharers in the mission? As pastors, bishops, and priests, are we conscious and convinced of the mission of the lay faithful, and do we give them the freedom to continue discerning, in a way befitting their growth as disciples, the mission which the Lord has entrusted to them? Do we support them and accompany them, overcoming the temptation to manipulate them or infantilize them?" In Francis, "Address to the Leadership of the Episcopal Conferences of Latin America during the General Coordination Meeting," Vatican website, July 28, 2013, 5, last accessed December 18, 2017, https://w2.vatican.va/content/francesco/en/speeches/2013/july/documents/papa-francesco_20130728_gmg-celam-rio.html.

30 Francis, "Presentation of the Christmas Greeting to the Roman Curia," Vatican website, December 22, 2016, 1, last accessed December 18, 2017, https://w2.vatican.va/content/francesco/en/speeches/2016/december/documents/papa-francesco_20161222_curia-romana.html.

31 Ibid., 15. 
A third source of social sin or structural sin in the Church comes up periodically in the pope's speeches or homilies (but not in his public writings) when he acknowledges that, in all of these areas, "the evil spirit [or, the devil] is afoot." As he puts it, "The decision for missionary discipleship will encounter temptation. It is important to know where the evil spirit is afoot in order to aid our discernment. It is not a matter of chasing after demons, but simply one of clear-sightedness and evangelical astuteness." 32

Pope Francis's call for an examination of conscience provides, in fact, an examination of consciousness, but it also brings to light the unconscious where opaque forces - not entirely derivative of and within the control of intentionality or will power or rationality - are at work. His treatment of pathologies of power, ideologies, and the demonic introduces such forces into our understanding of personal sin and social, structural sin. These categories exceed the domain of intentional subjects.

These categories introduce dark forces in the self and society that are unconscious and unintentional, and they can work behind the scenes or behind the backs of individuals or communities. But that is not to say that they cannot be engaged, contested, and resisted at the level of personal or collective consciousness and public contestation about structural reform. And this is the strength of Pope Francis's position. As a result, I believe that Pope Francis offers resources for the doctrine of social sin and institutional sin, and particularly the sinfulness of the Church, that exceed those developed by Pope John Paul II and Pope Benedict XVI. ${ }^{33}$ For Pope Francis, any discernment of spirits at work in these dynamics will inevitably include conflict and struggle, which should be negotiated at the intersection of personal engagement with the sense of the faith of the people of God and by confronting the depth and refractoriness of reality. These are precisely the basis for his program of pastoral reform associated with decentralization in the Church, and they require the practices of dialogical discernment and decision-making associat-

32 Francis, "Address to the Leadership of the Episcopal Conferences," 4.

33 I do not consider here the contribution of Pope Benedict XVI who did not write about social sin in the Church or society but did acknowledge structural sin, which he associated with original sin, a position that merits further investigation. See Daniel J. Daly, "Structures of Virtue and Vice," New Blackfriars 92 (May 2011): 341-357; Daniel K. Finn, "What is a Sinful Social Structure?" Theological Studies 77, no. 1 (2016): 136-164. 
ed with synodality at every level of the Church's organization.

The struggle against centralization and clericalism is not simply a matter that engages the energies of clergy, bishops, and cardinals. It is also a matter of personal and collective struggle that goes on in people's everyday lives, in cultures, and in structural patterns of the Church at every level. Theologians need to collaborate with clergy, religious, and lay people to create a synodal approach to discernment and decision-making that allows us to find our way together.

The Church's Role in Society: Decolonizing and Democracy

In the final section of this essay, I wish to comment on one significant implication of Pope Francis's ecclesiology pertaining to the Church's mission in society in Africa. Recently, the pope has begun to develop a critique of colonialism and has challenged Catholics and people of other faiths and worldviews to struggle against the forces of colonialism. I will describe his position in terms of decolonizing following the work of influential postcolonial theorists. ${ }^{34}$ Pope Francis is not the first pope to offer a critique of colonialism, which began in the mid-twentieth century with Pope Pius XII. ${ }^{35}$ Shortly thereafter, in 1965, CELAM began to develop a substantive critique of colonialism at their General Conference in Medellín, ${ }^{36}$ and more recently, used the term "decolonizing" in Aparecida in 2007. As we read there, "Present throughout the history of Afro-Americans has been social, economic, political, and especially racial, exclusion, where ethnic identity is a factor in social subordination .... [T] he decolonizing of minds and knowledge, recovery of historic

34 For more details, see Hinze, "Decolonizing Everyday Practices: Sites of Struggle in Church and Society," CTSA Proceedings 71 (2016), https://ejournals.bc.edu/ojs/index.php/ctsa/article/viewFile/9387/8403; and Abraham, "Postcolonial Hermeneutics and a Catholic (Post) Modernity," CTSA Proceedings 71 (2016)

35 Pope Pius XII addressed colonialism in his "Christmas 1954 Message," Vatican website, December 24, 1954, 15-28, last accessed December 18, 2017, https://w2.vatican.va/content/pius-xii/it/ speeches/1955/documents/hf_p-xii_spe_19551224_cuore-aperto.html; and "Christmas 1955 Message," Vatican website, December 24, 1955, 26-41, last accessed December 18, 2017. http:// w2.vatican.va/content/pius-xii/it/speeches/1955/documents/hf_p-xii_spe_19551224_cuore-aperto.html.

36 CELAM, Second General Conference of Latin American Bishops [at Medellín], 1 Justice, 13 (p. 63); 2 Peace, 2-10 (pp. 71-75); 10 Lay Movements, 2 (p. 165). Cf. 7 Pastoral Concern for the Elites, 17 (p. 133). 
24 | The Ecclesiology of Pope Francis and the Future of the Church in Africa

memory, and enhancement of intercultural spaces and relationships are conditions for affirming the full citizenship of these peoples." ${ }^{37}$

Since Pope Francis is the first pope from the global South, his emerging critique of the legacy of colonialism's historical forms and of the threats of new forms of colonialism merit our attention. I will offer three examples. Before I do so, it is helpful to understand Francis's critique of ideology, which emerged much earlier in his career and contributes to his views on colonialism. An ideology, as he speaks of it, is an idea, theory, or program that is developed and championed by an elitist group and posited as a reliable and totalizing - all-encompassing, one might say - truth. Ideology operates as an intellectually pure, rigorist, or gnostic hermeneutic of reality, developed and wielded by power elites over and against less powerful audiences including the poor, the vulnerable, and the marginalized. The pope contrasts ideological approaches to theory construction with positions based on a pastoral approach and social strategy that seek to gaze upon reality with the eyes of disciples, listening to the people of God's sense of the faith. ${ }^{38} \mathrm{He}$ speaks of certain economic positions ("market-based, consumerist"), cultural viewpoints ("throwaway culture"), and gender theories as ideologies, ${ }^{39}$ and this sheds light on his use of the term "ideological colonialism."

In January 2015 in the Philippines, Francis introduced the phrase "ideological colonialism" to contrast with the more commonly used term "political colonialism": "Let us be on guard against colonization by new ideologies." He continues, "Just as our peoples, at a certain moment of their history, were mature enough to say 'no' to all forms of political colonization, so too in our families we need to be very wise, very shrewd, very strong, in order to say 'no' to all attempts at an ideological colo-

37 CELAM, Concluding Documents of the Fifth General Conference of the Bishops of Latin American and the Caribbean (CreateSpace Independent Publishing Platform, 2013), 96.

38 Austen Ivereigh traces Bergoglio's treatment of ideology back to the 1970s; Ivereigh, The Great Reformer, 111, 115-116, 121-122, 183-184.

39 For an analysis of Pope Francis's views on gender ideology, see Traina, "Whose Sensus? Which Fidelium? Justice and Gender in a Global Church," in Learning from All the Faithful: A Contemporary Theology of the Sensus Fidei, eds. Bradford E. Hinze and Peter C. Phan (Pickwick Publications, 2017). 
nization of our families. ${ }^{" 40} \mathrm{He}$ used the same formula a second time later that year during his address to the General Assembly of the United Nations in September 2015, when he offered this statement:

Without the recognition of certain incontestable natural ethical limits and without the immediate implementation of those pillars of integral human development, the ideal of "saving succeeding generations from the scourge of war" [Charter of the United Nations, Preamble], and "promoting social progress and better standards of life in larger freedom" [ibid.], risks becoming an unattainable illusion, or even worse, idle chatter which serves as a cover for all kinds of abuse and corruption, or for carrying out an ideological colonization by the imposition of anomalous models and lifestyles which are alien to people's identity and, in the end, irresponsible. ${ }^{41}$

In July 2015, Pope Francis addressed popular movements of social activists Catholic and non-Catholic, religious and nonreligious - and raised the issue of colonialism. He identified several new forms of colonialism: one associated with money - corporations, loans, "free trade" treaties — that disproportionately affects workers and the poor; a second associated with the coordinated international action against corruption, drug cartels, and terrorism that too often proves ineffective and can "make matters worse"; and a third form related to an ideological colonialism that promotes "the monopolizing of the communications media, which would impose alienating examples of consumerism and a certain cultural uniformity." $\mathrm{He}$ challenged his audience, which includes many who are not Catholic or Christian (or believers at all), to "say NO ... to forms of colonialism old and new. Let us say YES to the encounter between peoples and cultures." ${ }^{42}$

40 Francis, "Meeting with Families," Vatican website, January 16, 2015, last accessed December 18, 2017, https://w2.vatican.va/content/francesco/en/speeches/2015/january/documents/papa-francesco_20150116_srilanka-filippine-incontro-famiglie.html.

41 Francis, "Address to the General Assembly of the United Nations," Vatican website. September 25, 2015, last accessed December 18, 2017, http://w2.vatican.va/content/francesco/en/speeches/2015/september/documents/papa-francesco_20150925_onu-visita.html.

42 Francis, "Address to the Second World Meeting of Popular Movements," Vatican website, November 5, 2016, Sec. 3.2, last accessed December 18, 2017, http://w2.vatican.va/content/francesco/ en/speeches/2016/november/documents/papa-francesco_20161105_movimenti-popolari.html. For the pope's first meeting with popular movements; see Francis, "Address to the Participants in 
When the pope traveled to eastern Africa in November of 2015, he did not speak explicitly about colonialism, but his remarks do reflect his views on the need to struggle against the influence of colonialism and neocolonialism on the continent of Africa. During his conversations with two different groups of young people, one in Kenya and another in Uganda, the pope listened as they discussed their struggles with tribalism, corruption, AIDS, and depression. In both cases, he urged them to struggle against despair and hopelessness and to find solace in prayer and in the Christian community. ${ }^{43}$ Without denying the various causes involved, he concentrated on the problems of recruiting young people to get involved in tribalism and corruption, and he spoke about the need for education and employment to fight against these temptations. I would argue that this is a vernacular expression of the need for decolonizing, for struggling against the negative results of colonialism that traumatize and wound psyches, bodies, and memories. Francis is encouraging young people to resist the powers of colonialism that are at work in their societies and to cultivate resilience and healing. He delivered similar messages to bishops, clergy, lay pastoral ministers, and the faithful people of God. Only by naming and analyzing the destructive powers of colonialism and neocolonialism will the Church be able to advance grassroots democracy in collaboration with people of other faiths and worldviews in the struggle against corruption, tribalism, and every form of violence, as well as economic forms of exclusion and extreme economic disparity and poverty.

What is the Catholic Church's role in promoting decolonizing regionally and in various local churches across Africa? Of course, this role must include pastoral outreach to Catholics like the young people from Kenya and Uganda who are struggling with the various psychological, bodily, and spiritual manifestations of colonialism and the colonial matrix of power. To do this, the Church with local

the World Meeting of Popular Movements," Vatican website, October 28, 2014, last accessed December 18, 2017, http://w2.vatican.va/content/francesco/en/speeches/2014/october/documents/ papa-francesco_20141028_incontro-mondiale-movimenti-popolari.html

43 Francis, "Address to Young People in Kasarani Stadium," Vatican website, November 27, 2015, last accessed December 18, 2017, https://w2.vatican.va/content/francesco/en/speeches/2015/november/documents/papa-francesco_20151127_kenya-giovani.html. 
lay people, clergy and religious women must explore what a pastoral program of decolonizing might mean in dioceses, parishes, and small Christian communities.

Decolonizing also requires that Catholic parishes and organizations encourage their members' involvement in fostering faith-based and broad-based (that is, nonfaith-based) forms of community organizing to promote grassroots democracy around basic areas of concern such as housing, economic initiatives, employment, health care, and education. Such community organizing efforts include faith-based groups, and as such Catholics must learn how to collaborate with other Christians - Anglicans, Pentecostals, and congregations from various evangelical traditions. These community organizing groups should also include Muslims and people from African Traditional Religions. In principle, organizations should welcome people with no religious affiliation who are members of associations, such as school groups, community centers, and business and labor organizations. And faith leaders need to be leadership training of faith leaders by organizations that have been effective in developing broad-based and faith-based community organizing. ${ }^{44}$

In conclusion, we have explored how Pope Francis has introduced a new phase in the reception of central teachings of Vatican II about the people of God, the sense of the faithful, the signs of the times, and the synodality of the Church. This vision of the Church is based on the central narrative drama of the eschatological pilgrim people of God, a Church of the poor and in solidarity with poor, marginalized people and the wounded earth. This vision of the Church provides the basis for the promotion of synodal deliberation in the Church, not only in expressions of the collegiality of bishops in the synod of bishops and episcopal conferences, but also in diocesan and parish councils and community forums that engage all the faithful people, and that strive to advance democracy throughout civil society. These themes

44 Pilot programs in building broad-based community organizing struggling against colonialism and for grassroots democracy are being developed in Rwanda, Haiti, Guatemala, and El Salvador by P.I.C.O., which stands for People Improving Communities through Organizing. For information about PICO's International program, see http://picointernational.org/about/. For information about community organizing in California, London, and New York, see Wood, Faith in Action: Religion, Race, and Democratic Organizing in America (Chicago: University of Chicago Press, 2002); Bretherton, Resurrecting Democracy: Faith, Citizenship, and the Politics of a Common Life (Cambridge: Cambridge University Press, 2015); and Hinze, Prophetic Obedience. 
28 The Ecclesiology of Pope Francis and the Future of the Church in Africa

are important, of course, for the universal Church, but they have distinctive promise and potential for the future of the Church in Africa in the promotion of decolonizing praxis by means of synodal styles of discernment and grassroots democracy. Let me finally note that Pope Francis's vision of the Church is not a repudiation of central motifs in the teachings of John Paul II and Benedict XVI, but provides a framework and foundation for the sacramental mystery of the Church as the body of Christ and the impetus for the advancement of communion with God and among the people of God and all of God's people. 


\section{BIBLIOGRAPHY}

Abraham, Susan. "Postcolonial Hermeneutics and a Catholic (Post) Modernity." CTSA Proceedings 71 (2016).

Bingemer, Lucchetti. "The Sensus Fidei in the Recent History of the Latin American Church." CTSA Proceedings 70 (2015): 48-59.

Bretherton, Luke. Resurrecting Democracy: Faith, Citizenship, and the Politics of a Common Life. Cambridge: Cambridge University Press, 2015.

CELAM. Second General Conference of Latin American Bishops [at Medellín], 2nd (1968): Bogotá, Colombia and Medellín, Colombia.

CELAM. Concluding Documents of the Fifth General Conference of the Bishops of Latin American and the Caribbean. CreateSpace Independent Publishing Platform, 2013.

Daly, Daniel J. "Structures of Virtue and Vice," New Blackfriars 92, (May 2011): 341-357.

Dyrberg, Torben B. Foucault on the Politics of Parrhesia. New York: Palgrave Macmillan, 2014.

Finn, Daniel K. "What is a Sinful Social Structure?” Theological Studies 77, no. 1 (2016): 136-164.

Francis. "Address at the Ceremony Commemorating the 50th Anniversary of the Institution of the Synod of Bishops." Vatican website. October 17, 2015. Last accessed December 18, 2017. http://w2.vatican.va/content/francesco/en/ speeches/2015/october/documents/papa-francesco_20151017_50-anniversario-sinodo.html.

"Address to the General Assembly of the United Nations." Vatican website. September 25,2015. Last accessed December 18, 2017. http://w2.vatican. $\mathrm{va} /$ content/francesco/en/speeches/2015/september/documents/papa-francesco_20150925_onu-visita.html. 
30 | The Ecclesiology of Pope Francis and the Future of the Church in Africa

.Address to the Leadership of the Episcopal Conferences of Latin America During the General Coordination Meeting." Vatican website. July 28, 2013. Last accessed December 18, 2017. https://w2.vatican.va/content/francesco/ en/speeches/2013/july/documents/papa-francesco_20130728_gmg-celamrio.html.

.Address to the Participants in the World Meeting of Popular Movements." Vatican website. October 28, 2014. Last accessed December 18, 2017. http:// w2.vatican.va/content/francesco/en/speeches/2014/october/documents/papa-francesco_20141028_incontro-mondiale-movimenti-popolari.html.

. "Address to the Second World Meeting of Popular Movements." Vatican website. November 5, 2016. Last accessed December 18, 2017. http:// w2.vatican.va/content/francesco/en/speeches/2016/november/documents/papa-francesco_20161105_movimenti-popolari.html.

. "Address to Young People in Kasarani Stadium." Vatican website. November 27, 2015. Last accessed December 18, 2017. https://w2.vatican.va/ content/francesco/en/speeches/2015/november/documents/papa-francesco_20151127_kenya-giovani.html.

. Evangelii Gaudium [Apostolic Exhortation on the Proclamation of the Gospel in Today's World]. Vatican website. November 24, 2013. Last accessed December 18, 2017. http://w2.vatican.va/content/francesco/en/apost_exhortations/documents/papa-francesco_esortazione-ap_20131124_evangelii-gaudium.html.

. "Greeting to the Synod Fathers during the First General Congregation of the Third Extraordinary General Assembly of the Synod of Bishops." Vatican website. October 6, 2014. Last accessed December 18, 2017. https://w2.vatican.va/content/francesco/en/speeches/2014/october/documents/papa-francesco_20141006_padri-sinodali.html. 
. Laudato Si'[Encyclical Letter on Care for Our Common Home]. Vatican website. May 24, 2015. Last accessed December 18, 2017. http://w2.vatican.

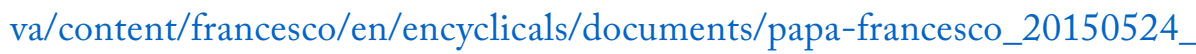
enciclica-laudato-si.html.

."Meeting with the Clergy, Consecrated People, and Members of Diocesan Pastoral Councils." Vatican website. October 24, 2013. Last accessed December 18, 2017. https://w2.vatican.va/content/francesco/en/speeches/2013/october/documents/papa-francesco_20131004_clero-assisi.html.

“Meeting with Families.”Vatican website. January 16, 2015. Last accessed December 18, 2017. https://w2.vatican.va/content/francesco/en/speeches/2015/january/documents/papa-francesco_20150116_srilanka-filippine-incontro-famiglie.html.

"Presentation of the Christmas Greeting to the Roman Curia." Vatican website. December 22, 2016. Last accessed December 18, 2017. https://w2. vatican.va/content/francesco/en/speeches/2016/december/documents/papa-francesco_20161222_curia-romana.html.

Hinze, Bradford E. "Decolonizing Everyday Practices: Sites of Struggle in Church and Society," CTSA Proceedings 71 (2016). https://ejournals.bc.edu/ojs/index.php/ctsa/article/viewFile/9387/8403.

. Practices of Dialogue in the Roman Catholic Church. New York: Continuum 2006.

- "Vatican II and U.S. Catholic Communities: Promoting Grassroots Democracy." In The Legacy of Vatican II, edited by Massimo Faggioli and Andrea Vicini, 152-181. New York: Paulist Press, 2015.

- Prophetic Obedience: Ecclesiology for a Dialogical Church. Maryknoll, NY: Orbis Books, 2016.

Ivereigh, Austin. The Great Reformer: Francis and the Making of a Radical Pope. New York: Picador, 2015. 
32 The Ecclesiology of Pope Francis and the Future of the Church in Africa

John Paul II, Ordinatio Sacerdotalis [Apostolic Letter on Reserving Priestly Ordination to Men Alone]. Vatican website. May 5, 1994. Last accessed December 18, 2017. https://w2.vatican.va/content/john-paul-ii/en/apost_letters/1994/documents/hf_jp-ii_apl_19940522_ordinatio-sacerdotalis.html.

. Pastores Gregis [Post-Synod Apostolic Exhortation for the Hope of the World]. Vatican website. October 16, 2003. Last accessed December 18, 2017. http://w2.vatican.va/content/john-paul-ii/en/apost_exhortations/documents/ hf_jp-ii_exh_20031016_pastores-gregis.html.

Leo XIII. Rerum Novarum [Encyclical on Capital and Labor]. Vatican website. May 15, 1891. Last accessed December 18, 2017. http://w2.vatican.va/content/leo-xiii/en/encyclicals/documents/hf_1-xiii_enc_15051891_rerum-novarum.html.

McElwee, Joshua J. "Pope Francis: 'I would love a church that is poor.” National Catholic Reporter, March 16, 2013. https://www.ncronline.org/blogs/francis-chronicles/pope-francis-i-would-love-church-poor.

Melloni, Alberto. "Poverty of the Church-Poverty of Culture: A Contribution of Giuseppi Dossetti to Vatican II.” Theological Studies 75 (2014): 485-501.

Paul VI. Lumen Gentium [Dogmatic Constitution on the Church]. Vatican website. November 21, 1964. Last accessed December 18, 2017. http://www.vatican.va/ archive/hist_councils/ii_vatican_council/documents/vat-ii_const_19641121_ lumen-gentium_en.html.

"About: What is Pico International?" Pico International. Last accessed December 18, 2017. http://picointernational.org/about/.

Pius XII. “Christmas 1954 Message.”Vatican website. December 24, 1954. Last accessed December 18, 2017. https://w2.vatican.va/content/pius-xii/it/speeches/1955/documents/hf_p-xii_spe_19551224_cuore-aperto.html. 
. “Christmas 1955 Message.” Vatican website. December 24, 1955. Last accessed December 18, 2017. http://w2.vatican.va/content/pius-xii/it/speeches/1955/documents/hf_p-xii_spe_19551224_cuore-aperto.html

Reese, Thomas S. J. "How the Synod Process is Different under Pope Francis." National Catholic Reporter, October 17, 2014. https:/www.ncronline.org/ blogs/faith-and-justice/how-synod-process-different-under-pope-francis.

Scannone, Juan Carlos. "Gaudium et Spes and the Unfinished Agenda of Vatican II” Filmed November 12, 2015 at Georgetown University, Washington, D.C. Video, 1:46:17. https://youtu.be/94fs48fzsPg

Spadaro, Antonio. “A Big Heart Open to God.” America, September 30, 2013. https://www.americamagazine.org/faith/2013/09/30/big-heart-open-god-interview-pope-francis.

Traina, Christina. "Whose Sensus? Which Fidelium? Justice and Gender in a Global Church," In Learning from All the Faithful: A Contemporary Theology of the Sensus Fidei, edited by Bradford E. Hinze and Peter C. Phan. Pickwick Publications, 2017.

Wood, Richard. Faith in Action: Religion, Race, and Democratic Organizing in America. Chicago: University of Chicago Press, 2002. 